\title{
Metacognitive regulation, basic psychological needs and subjective vitality of first year university students
}

\author{
D. N. Makarova \\ 5, ul. Venskaya, Kudrovo, Leningradskaya oblast', 188692, Russian Federation
}

For citation: Makarova D. N. Metacognitive regulation, basic psychological needs and subjective vitality of first year university students. Vestnik of Saint Petersburg University. Psychology, 2021, vol. 11, issue 1, pp. 63-71. https://doi.org/10.21638/spbu16.2021.104

Intellectual performance is influenced by many factors, besides intelligence and cognitive skills, including the type of motivation and metacognitive regulation. The authors of the article became interested in the question of whether there is a connection between productivity of metacognitive regulation and different types of motivation (extrinsic and intrinsic). According to the self-determination theory (SDT), maintaining intrinsic (autonomous) motivation requires satisfying of one's basic psychological needs. Also, SDT distinguishes the concepts of self-control and self-regulation (a particular case of which is metacognitive regulation) and postulates the existence of a connection between self-regulation and the level of subjective vitality. The aim of the study was to test the following hypothesis: the higher the level of satisfaction of three basic psychological needs and the level of subjective vitality, the higher the level of productivity of metacognitive regulation of intellectual performance. Participants (first year university students, $n=116,70$ men) completed Russian versions of two questionnaires, created inside the SDT paradigm: "Basic Psychological Need Satisfaction and Frustration Scale" and "Subjective Vitality Scale". To assess the productivity of metacognitive regulation of intellectual activity, a new modified version of the questionnaire "Features of intellectual activity" (D. N. Makarova, M. V. Osorina) was used. Multiple regression analysis was performed using SPSS to test the hypothesis. The final model, which explains $31.4 \%$ of the variance of the dependent variable, shows that the higher the level of subjective vitality and the levels of satisfaction of need in autonomy and competence, the higher the level of productivity of metacognitive regulation of intellectual performance. The proposed hypothesis was partly refuted: no relationship was found between the level of satisfaction of the need in relatedness and the level of productivity of metacognitive regulation.

Keywords: metacognitive regulation, basic psychological needs, subjective vitality, patterns of metacognitive regulation.

Intellectual performance is influenced by a great number of factors besides intelligence and skills, including type of motivation $[1 ; 2]$ and metacognition $[3 ; 4]$.

Several years ago while conducting a study on intellectual performance we stumbled upon an interesting conundrum: subjects with normal intelligence or higher made unexpected and trivial mistakes inconsistent with their IQ level [5]. Some of our colleagues faced the same issue and discovered that at least some part of such mistakes was made due to lack of metacognitive regulation skills $[6 ; 7]$. This shifted our research focus from intellectual performance in its connection with intelligence and cognitive skills to metacognitive regulation and its role in intellectual success.

(C) St. Petersburg State University, 2021 
Most of the studies on the subject of metacognitive regulation we encountered during our literature analysis fell into one of the two categories. First category included experimental studies of regulatory processes occurring during the problem solving process focused on particular metacognitive skills [8-11]. The second category consisted of research on metacognitive regulation in general (viewed as an ability to regulate one's intellectual activity) and its connections with cognitive phenomena (such as intelligence, intellectual performance etc.) [3;12-15].

We wanted to study metacognitive regulation as a whole, including both the organization of intellectual activity (planning, time management, etc.) and the regulation of cognitive processes during the problem solving process (information search strategies, choice of a solution, etc.). That is why we have chosen the inductive way of studying this phenomenon.

In our previous research, we discovered and described patterns of metacognitive regulation (PMR) - which are regularly recurring stable mental programs aimed at achieving high levels of intellectual performance manifesting themselves as particular behavior patterns, which can be observed [16]. Our subsequent study showed that the same PMRs can be observed in different samples [17].

Our long-term goal was to uncover the place of metacognitive regulation in a complex system of phenomena - both cognitive and non-cognitive - which influence intellectual performance. As far as we could tell from our analysis of existing studies relations between metacognitive regulation and cognitive phenomena have been investigated quite thoroughly [3; 4; 8-15]. Thus after we established ontological status of PMRs, we started the search for their non-cognitive correlates.

The qualitative data we gathered during our first study [16] was the basis for the list of possible non-cognitive correlates we comprised:

1) one's emotions and feelings during intellectual activity;

2) type of motivation;

3) self-efficacy.

The results of our subsequent study showed that some of PMRs are connected with self-efficacy [18]. We also discovered connections between PMRs and different emotions and feelings (such as joy, disgust, interest and excitement). The association between PMRs and different types of motivation (such as extrinsic and intrinsic) stayed unclear [18]. Therefore, we decided to broaden our search and study PMRs in the context of another motivation theory.

Self-determination theory (SDT), suggested by E. Deci and R. Ryan [1], is one of the most interesting and promising in nowadays motivation research. The authors suggest to identify three different motivational orientations (also called causality orientations): the autonomy orientation - intrinsic (autonomous) motivation and well-integrated extrinsic motivation, the controlled orientation - external and introjected regulation, and the impersonal orientation - amotivation and lack of intentional action (see Fig. 1) [19]. The authors define them as "propensities to focus on certain aspects of environments and inner capacities that concern motivation and causes of their behaviors", which "affect people's situation-specific motivation, as well as their general need satisfaction, behavior, and experience" [1, p. 218].

A big body of data suggests that there is a connection between autonomous motivation and high productivity in different areas: political activity [21], physical exercises 


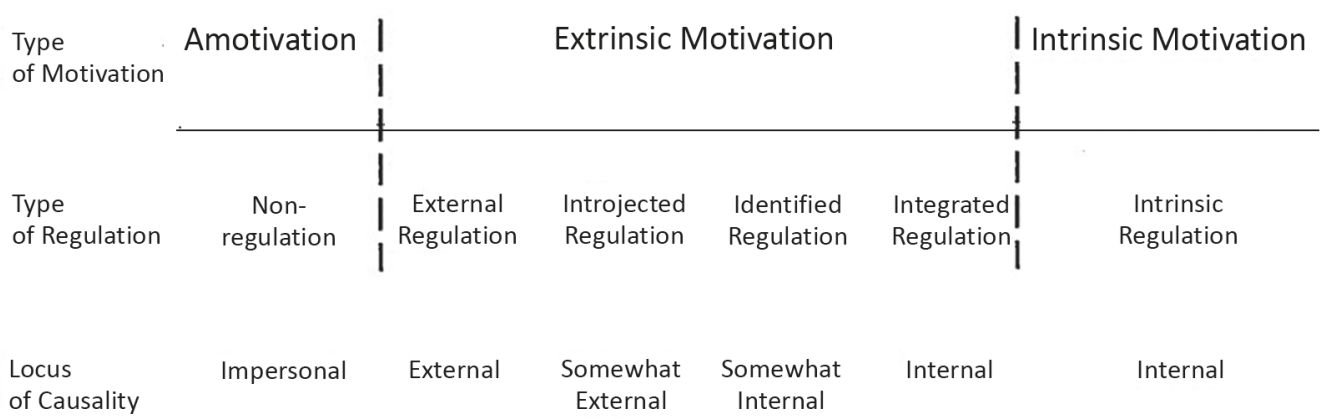

Fig. 1. SDT continuum [20, p. 237]

[22] and even personal relationships [23]. However, for our research the most interesting are the results of SDT studies in areas of academic and work performance. It was shown that there is a connection between autonomous motivation and high grades [24]. Also researchers found higher quality of learning [25] and fewer cases of expelling [26] among students with autonomous motivation. As for the work domain, the association of autonomous (intrinsic) motivation with effective performance was shown in numerous studies [1], including a recent meta-analysis [4]. These data suggest that intellectual performance, supported by activation of patterns of metacognitive regulation, may also be connected with dominating motivation type - autonomous or controlled.

According to SDT, satisfaction of three basic psychological needs (BPN) - in autonomy, competence and relatedness - has a great influence on subjective vitality and motivation type: their satisfaction mediates "wellness, vitality and the motivational status of the individual" [1, p. 242]. Autonomy (or to be more precise - reflective autonomy) is "acting with a sense of choice" [1, p. 231]. Competence is defined by SDT as one's feeling of "ownership of the activities" at which one succeeds [1, p. 95]. As for relatedness, it is viewed as "feeling of belonging and of being significant or mattering in the eyes of others" [1, p. 96].

The relationship between BPN satisfaction and autonomous (or intrinsic) versus controlled (or extrinsic) motivation is complex. Intrinsically motivated behavior is not aimed at satisfying BPN per se: its starting point is person's interest. But to be maintained, it requires "satisfaction of the needs in autonomy and competence" [19, p. 233].

The authors of SDT posit that there is a connection between BPN satisfaction and wellness or well-being: "Failure to satisfy any of these needs will be manifested in diminished growth, integrity and wellness" [1, p.242]. One of the main properties of wellness is "access to, and exercise of one's human capacities and true self-regulation" [1, p. 241]. Moreover, they state that "well-being... represents a fullness and vitality of organismic functioning in which people are aware, psychologically flexible, and integrated rather than depleted, defensive, rigid or compartmentalized" [1, p.241]. In our opinion, all the aforementioned characteristics, such as awareness, psychological flexibility, exercise of capabilities and true self-regulation, describe a state of mind optimal for successful intellectual performance.

Subjective vitality is another important concept of SDT. The authors define is as "energy, available to self" and emphasize that it refers to more than just physical state, as 
"it also reflects satisfaction versus thwarting of basic psychological needs for autonomy, competence and relatedness" [1, p. 259]. Subjective vitality is interconnected with type of motivation, as "controlling regulation (i. e. self-control)... is especially likely to diminish subjective vitality" and "when people are autonomously motivated, they will be... potentially enhancing their vitality" [1, p. 259].

The authors also make a distinction between self-control and self-regulation, which is important for our research: "self-control typically entails external and introjected regulations. Introjection in particular is an internally controlled form of regulation in which one part of personality overruns another, whereas true self-regulation refers to autonomous regulation consisting of more fully integrated regulation and intrinsic motivation" [1, p.259]. Therefore the closer on the SDT continuum the person is to the right end (where the autonomous regulation lies), the more "intrinsic" and less energy draining is their self-regulation.

Since metacognitive regulation is a case of self-regulation, we speculated that autonomous motivation type (as opposed to the controlled one) combined with higher subjective vitality is associated with more productive patterns of metacognitive regulation. And as BPN satisfaction is one of the two main conditions of maintaining autonomously motivated behavior, we decided to measure it. Therefore, we studied PMRs - and their relation with three basic psychological needs and subjective vitality.

\section{Method}

The aim of this study was to test the following hypothesis: the higher are the levels of satisfaction of three basic psychological needs and the level of subjective vitality, the higher is the level of productivity of metacognitive regulation of intellectual performance.

Our participants were first year university students ( $n=116,70$ men, 46 women). We asked them to fill out Russian versions of two questionnaires, created inside the SDT paradigm: "Basic Psychological Need Satisfaction and Frustration Scale" (BPN) [27] and "Subjective Vitality Scale (Individual Difference Level Version)" (SV) [28]. The Russian versions were the result of a four-staged process: we performed English-to-Russian translation, and two other interpreters conducted a backward Russian-to-English translation. Then we compared English versions and discussed the differences with the experts. Modification of Russian texts according to the ideas formulated at the previous stage was the last step.

In order to assess productivity of metacognitive regulation of intellectual performance we used a new modified version of "Features of intellectual performance" questionnaire (FIP; created by D.N. Makarova, M. V.Osorina). In this modified version (which has not been published yet) PMRs were grouped into 13 dyads (part I of the questionnaire) and 5 triads (part II). There were 18 questions altogether instead of 40 as in the initial version [17]. The idea was to create scales, in each of which the left pole of the scale presents an unproductive PMR at its worst, and the right pole - a productive "variant" of the same PMR (see Fig. 2).

As before [17], the PMRs were described in a form of a first person statement. In five triads there also was a middle "variant" (see Fig. 3).

The idea was that the more unproductive PMRs there are in a typical behavior repertoire of a person, the smaller the total sum of scores for all the answers is, and vice 


\begin{tabular}{|l|l|l|l|l|l|l|}
\hline $\begin{array}{l}\text { If I can not solve a problem at first } \\
\text { attempt, I stop trying, because I deem it } \\
\text { unlikely that I would succeed }\end{array}$ & $\mathbf{1}$ & $\mathbf{2}$ & $\mathbf{3}$ & $\mathbf{4}$ & $\mathbf{5}$ & $\begin{array}{l}\text { I stay calm when I cannot find a } \\
\text { solution to a problem right away, } \\
\text { because not everything can be done at } \\
\text { the first try }\end{array}$ \\
\hline
\end{tabular}

Fig. 2. Sample dyad

\begin{tabular}{|l|l|l|l|l|}
\hline $\begin{array}{l}\text { It is difficult for me to start working } \\
\text { on an intellectual task even when it is } \\
\text { interesting for me. I need someone or } \\
\text { something to make me begin }\end{array}$ & $\begin{array}{l}\text { It is easy for me to start working } \\
\text { on an intellectual task only when I } \\
\text { made a decision to do it }\end{array}$ & $\begin{array}{l}\text { Even when I have to work on an in- } \\
\text { tellectual task, which was given to } \\
\text { me, I always try to make it interest- } \\
\text { ing for myself }\end{array}$ \\
\hline 1 & 2 & 3 & 4 & 5 \\
\hline
\end{tabular}

Fig. 3. Sample triad

versa. Though PMRs can be investigated separately, in this particular study we used our questionnaire to assess general productivity level of metacognitive regulation of our participants.

\section{Results and discussion}

We conducted multiple regression analysis (backward method) using SPSS in order to test our hypothesis. We used FIP (sum of scores for all the answers) as a dependent variable. The levels of satisfaction of three basic psychological needs - autonomy (A), competence $(\mathrm{C})$ and relatedness $(\mathrm{R})$ and the level of subjective vitality (SV; 6-item version) were independent variables. One of the independent variables $-\mathrm{R}-$ was excluded from the model, and three stayed: A, C and SV (see table).

Table. The results of multiple regression analysis (backward method)

\begin{tabular}{|c|c|c|c|c|c|c|}
\hline & \multirow{2}{*}{ Model } & \multicolumn{2}{|c|}{ Unstandardized Coefficients } & \multirow{2}{*}{$\begin{array}{c}\begin{array}{c}\text { Standardized } \\
\text { Coefficients }\end{array} \\
\text { beta }\end{array}$} & \multirow{2}{*}{$\mathrm{t}$} & \multirow{2}{*}{ Sig. } \\
\hline & & B & std error & & & \\
\hline \multirow{5}{*}{1} & (Constant) & 55.374 & 2.375 & & 23.316 & 0.000 \\
\hline & A & 0.421 & 0.155 & 0.266 & 2.720 & 0.008 \\
\hline & $\mathrm{C}$ & 0.296 & 0.148 & 0.219 & 1.996 & 0.048 \\
\hline & $\mathrm{R}$ & 0.080 & 0.133 & 0.059 & 0.603 & 0.548 \\
\hline & SV & 0.163 & 0.118 & 0.146 & 1.376 & 0.171 \\
\hline \multirow{4}{*}{2} & (Constant) & 55.300 & 2.365 & & 23.383 & 0.000 \\
\hline & A & 0.412 & 0.154 & 0.260 & 2.680 & 0.008 \\
\hline & $\mathrm{C}$ & 0.325 & 0.140 & 0.241 & 2.317 & 0.022 \\
\hline & SV & 0.187 & 0.111 & 0.168 & 1.686 & 0.095 \\
\hline
\end{tabular}




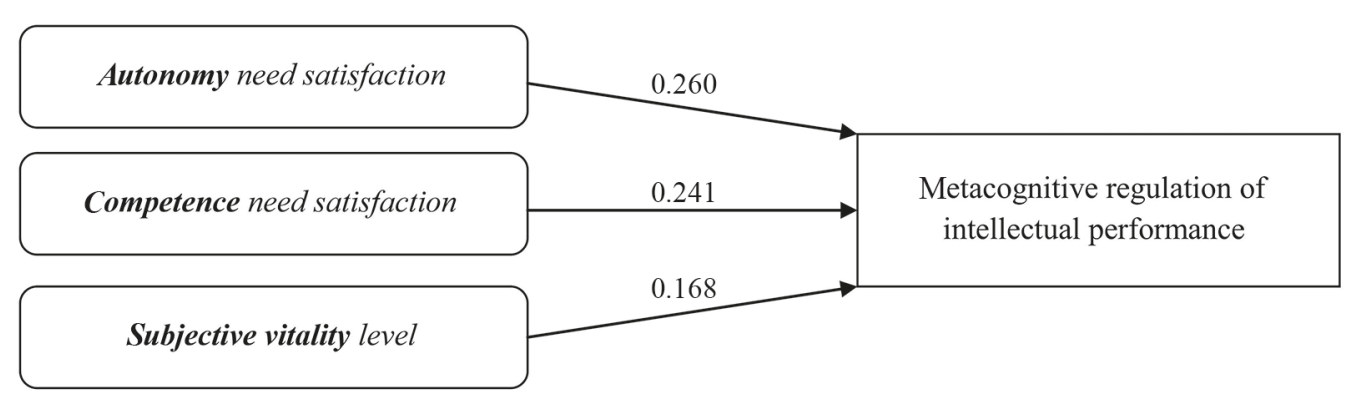

Fig. 4. The results of multiple regression analysis (with standardized coefficients): the final model

The final model, which explains $31.4 \%$ of variance of dependent variable (FIP), can be described with the following equation: FIP $=55.3+(0.412 \mathrm{~A})+(0.325 \mathrm{C})+(0.187 \mathrm{SV})$ (see Fig. 4). This model shows that the higher the level of subjective vitality and the levels of satisfaction of need in autonomy and competence, the higher is the level of productivity of metacognitive regulation of intellectual performance (MRIP). Also these results mean that our hypothesis was partly refuted: we found no connection between the level of satisfaction of need in relatedness and the level of productivity of MRIP.

According to the model we got, the level of autonomy need satisfaction has the biggest impact on productivity of MRIP (beta $=0.260$ ). It goes in line with SDT ideas: autonomy need is viewed as the main one in terms of influence on motivation type [1]. Moreover, this makes perfect sense: not only because autonomy facilitates the satisfaction of another two needs, but also because it is the essence of autonomous (intrinsic) motivation. Acting out of free will eliminates the necessity to overcome one's inner resistance and leaves all mental resources available for spending on cognitive and metacognitive actions required by a task at hand.

The level of competence need satisfaction was second in terms of the coefficient size (beta $=0.241$ ). That was also to be expected: SDT states that effective internalization is highly relevant to satisfying the need of competence. And effective internalization puts a person close to the right end of SDT continuum, i. e. makes motivation more intrinsic, which in turn leads to more effective self-regulation. Also competence need satisfaction results in higher levels of self-efficacy, which is known to be associated with higher levels of intellectual performance [12;29].

And the level of subjective vitality has the least impact (beta $=0.168$ ). One possible explanation is that subjective vitality in itself is influenced by (dis)satisfaction of three basic psychological needs, and therefore can be viewed as their derivative.

At this stage of our research we cannot make substantiated claims on the subject of whether or not there is a causal relationship between the aforementioned phenomena. One may speculate that metacognitive skills develop throughout adolescence and early adulthood, whereas basic psychological needs are being either satisfied or thwarted from earlier age - which supposedly makes their levels the cause, and metacognitive regulation productivity level - the result.

However, according to SDT, psychological need satisfaction levels are not set in stone: they vary within people over time - which in turn leads to shifts in the degree to which 
the motivation is autonomous. And the closer one gets to the right end of the SDT continuum, the more 'intrinsic' and effective becomes their self-regulation (which includes metacognitive regulation).

This does not imply that controlled motivation impairs metacognitive skills and autonomous motivation somehow makes them better. We think that being closer to the right end of the SDT continuum puts one in such a state of mind, which enables a person to effectively apply metacognitive skills they already have, whereas being on the opposite end might impede such application.

So if we imagine that a person keeps 'sliding' back and forth on the SDT continuum - due to inner and outer changes - we can see how it is possible for basic psychological needs satisfaction levels and metacognitive regulation productivity level to change interdependently without either one being the cause of variations of the other.

\section{Limitations and conclusion}

The major limitation of this study is the homogeneity of the sample, as it consists only of first year university students. Therefore, the next step would be to test the same hypothesis on the bigger sample of adults, which engage in intellectual activity on the regular basis.

The main finding of this study was the correlation between the level of productivity of metacognitive regulation of intellectual performance and the level of subjective vitality and the levels of satisfaction of need in autonomy and competence. It means that in our sample students with better metacognitive skills had higher levels of autonomy and competence needs satisfaction and subjective vitality, and those with less productive metacognitive regulation felt less autonomous, less competent and less energetic (and vice versa).

On the basis of this finding we may hypothesize that creating a learning environment promoting autonomy and competence need satisfaction would lead to better intellectual performance via more productive metacognitive regulation.

\section{References}

1. Ryan R. M., Deci E. L. Self-determination theory. Basic Psychological Needs in Motivation, Development and Wellness. New York, Guilford Press, 2017.

2. Gagne M., Deci E. L. Self-determination Theory and Work Motivation. Journal of Organizational Behavior, 2005, vol. 26, pp. 331-362.

3. Ohtani K., Hisasaka T. Beyond intelligence: a meta-analytic review of the relationship among metacognition, intelligence, and academic performance. Metacognition Learning, 2018, vol. 13 (2), pp. 179-212.

4. Cerasoli C. P., Nicklin J. M., Ford M. T. Intrinsic motivation and extrinsic incentives jointly predict performance: A 40-year meta-analysis. Psychological Bulletin, 2014, vol. 140 (4), pp. 980-1008.

5. Makarova D. N. Manifestation of intellectual competencies while solving cognitive tasks of different types. Master degree thesis. Saint Petersburg, 2014. (In Russian)

6. Osorina M. V., Shcherbakova O. V., Avanesyan M. O. Problems of metacognitive regulation: standards and non-productive patterns of intellectual performance. Vestnik of Saint Petersburg University. Sociology, 2011, iss. 2, pp. 32-43. (In Russian)

7. Shcherbakova O. V. Information and energy aspects of organization of some patterns of metacognitive regulation. Vestnik of Saint Petersburg University. Sociology, 2012, iss. 3, pp. 103-114. (In Russian)

8. Veenman M. V.J., Spaans M.A. Relation between intellectual and metacognitive skills: Age and task differences. Learning and Individual Differences, 2005, vol. 15, pp. 159-176.

9. van der Stel M., Veenman M. V.J. Relation between intellectual ability and metacognitive skillfulness as predictors of learning performance of young students performing tasks in different domains. Learning and Individual Differences, 2008, vol. 18, pp. 128-134. 
10. van der Stel M., Veenman M. V.J. Metacognitive skills and intellectual ability of young adolescents: a longitudinal study from a developmental perspective. European Journal of Psychology of Education, 2014, vol. 29, pp. 117-137.

11. Veenman M. V.J., van Cleef, D. Measuring metacognitive skills for mathematics: students' selfreports versus on-line assessment methods. ZDM Mathematics Education, 2019, vol. 51, p. 691.

12. Stephanou G., Mpiontini M. Metacognitive Knowledge and Metacognitive Regulation in Self-Regulatory Learning Style, and in Its Effects on Performance Expectation and Subsequent Performance across Diverse School Subjects. Psychology, 2017, vol. 8, pp. 1941-1975.

13. Dent A.L., Koenka A.C. The relation between self-regulated learning and academic achievement across childhood and adolescence: a meta-analysis. Educational Psychology Review, 2016, vol. 28, pp. 425-474.

14. Cho M., Shen D. Self-regulation in online learning. Distance Education, 2013, vol. 34 (3), pp. 290-301.

15. Lee H. W., Lim K. Y., Grabowski B. L. Improving self-regulation, learning strategy use, and achievement with metacognitive feedback. Educational Technology Research and Development, 2010, vol. 58, pp. 629-648.

16. Makarova D. N. Individual Patterns of Metacognitive Regulation of Students' Intellectual Activity. Petersburg Psychological Journal, 2018, no. 22. (In Russian)

17. Makarova D. N. Productive and unproductive patterns of metacognitive regulation of intellectual performance. Vestnik of Saint Petersburg University. Psychology, 2020, vol. 10, iss. 2, pp. 184-193. (In Russian)

18. Makarova D. N. Productive and unproductive patterns of metacognitive regulation of intellectual performance. XVI European Congress of Psychology (ECP 2019) 2-5 July 2019. Moscow, Moscow University Press, pp. 1126-1227.

19. Ryan R. M., Deci E. L. Self-determination Theory and the Facilitation of Intrinsic Motivation, Social Development and Well-being. American Psychologist, 2000, vol. 55 (1), pp. 68-78.

20. Deci E. L., Ryan R. M. The "What" and "Why" of Goal Pursuits: Human Needs and the Self-Determination of Behavior. Psychological Inquiry, 2000, vol. 11, no. 4, pp. 227-268.

21. Koestner R., Losier G. F., Vallerand R. G., Carducci D. Identified and introjected forms of political internalization: Extending self-determination theory. Journal of Personality and Social Psychology, 1996, vol. 70, pp. 1025-1036.

22. Chatzisarantis N.L.D., Biddle S.G.H., Meek G. A. A self-determination theory approach to the study of intentions and the intention-behavior relationship in children physical activity. British Journal of Health Psychology, 1997, vol. 2, pp. 343-360.

23. Blais M. R., Sabourine S., Boucher C., Vallerand R. J. Toward a motivational model of couple happiness. Journal of Personality and Social Psychology, 1990, vol. 59, pp. 1021-1031.

24. Miserandino M. Children who do well in school: Individual differences in perceived competence and autonomy in above average children. Journal of Educational Psychology, 1996, vol. 88, pp. 203-214.

25. Grolnick W. S., Ryan R. M. Autonomy in children's learning: An experimental and individual difference investigation. Journal of Personality and Social Psychology, 1987, vol. 52, pp. 890-898.

26. Vallerand R. J., Bissonnette R. Intrinsic, extrinsic, and amotivational styles as predictors of behavior: A prospective Study. Journal of Personality, 1992, vol. 60, pp. 599-620.

27. Chen B., Vansteenkiste M., Beyers W., Boone L., Deci E. L., Duriez B., Lens W., Matos L., Mouratidis A., Ryan R. M., Sheldon K. M., Soenens B., Van Petegem S., Van der Kaap-Deeder J., Verstuyf J. Basic psychological need satisfaction, need frustration, and need strength across four cultures. Motivation and emotion, vol. 39, pp. 216-236.

28. Ryan R.M., Frederick C.M. On energy, personality and health: subjective vitality as a dynamic reflection of well-being. Journal of personality, vol. 65, pp. 529-565.

29. Zuffianò A., Alessandri G., Gerbino M., Luengo Kanacri B.P., Di Giunta L., Milioni M., Caprara G.V. Academic achievement: The unique contribution of self-efficacy beliefs in self-regulated learning beyond intelligence, personality traits, and self-esteem. Learning and Individual Differences, vol. 23, pp. 158162.

Received: October 20, 2020 Accepted: December 10, 2020

Author's information:

Daria N.Makarova - d.makarova23@gmail.com 


\title{
Метакогнитивная регуляция, базовые психологические потребности и субъективная витальность студентов-первокурсников
}

\author{
Д. Н. Макарова \\ Российская Федерация, 188692, Ленинградская обл., Кудрово, ул. Венская, 5
}

Для цитирования: Makarova D. N. Metacognitive regulation, basic psychological needs and subjective vitality of first year university students // Вестник Санкт-Петербургского университета. Психология. 2021. Т. 11. Вып. 1. С. 63-71.

https://doi.org/10.21638/spbu16.2021.104

На успешность интеллектуальной деятельности влияет множество факторов помимо интеллекта и когнитивных навыков, включая тип мотивации и метакогнитивную регуляцию. Нас заинтересовал вопрос о том, существует ли связь между продуктивностью метакогнитивной регуляции и разными типами мотивации (внешней и внутренней). Согласно теории самодетерминации, для поддержания внутренней (автономной) мотивации необходимо, чтобы были удовлетворены базовые психологические потребности субъекта. Также упомянутая выше теория разводит понятия самоконтроля и саморегуляции (частным случаем которой является метакогнитивная регуляция) и постулирует существование связи между нею и уровнем субъективной витальности. Целью данного исследования была проверка следующей гипотезы: чем выше уровень удовлетворения трех базовых психологических потребностей и уровень субъективной витальности, тем выше уровень продуктивности метакогнитивной регуляции интеллектуальной деятельности. Мы попросили участников нашего исследования (студентов первого курса, $n=116,70$ мужчин) заполнить русскоязычные версии двух опросников, созданных в рамках теории самодетерминации: «Шкала удовлетворения и фрустрации базовых психологических потребностей» и «Шкала субъективной витальности». Для оценки продуктивности метакогнитивной регуляции интеллектуальной деятельности использовалась новая модифицированная версия нашего опросника «Особенности интеллектуальной деятельности» (Д.Н. Макарова, М.В.Осорина). Мы провели множественный регрессионный анализ с помощью SPSS, чтобы проверить нашу гипотезу. Итоговая модель, объясняющая 31,4 \% дисперсии зависимой переменной, показывает, что чем выше уровень субъективной витальности и уровни удовлетворения потребностей в автономии и компетентности, тем выше уровень продуктивности метакогнитивной регуляции интеллектуальной деятельности. Наша гипотеза была частично опровергнута: мы не обнаружили связи между уровнем удовлетворения потребности в связанности и продуктивностью метакогнитивной регуляции.

Ключевые слова: метакогнитивная регуляция, базовые психологические потребности, субъективная витальность, паттерны метакогнитивной регуляции.

Статья поступила в редакцию 20 октября 2020 г.; рекомендована в печать 10 декабря 2020 г.

Контактная информация:

Макарова Дарья Николаевна - d.makarova23@gmail.com 